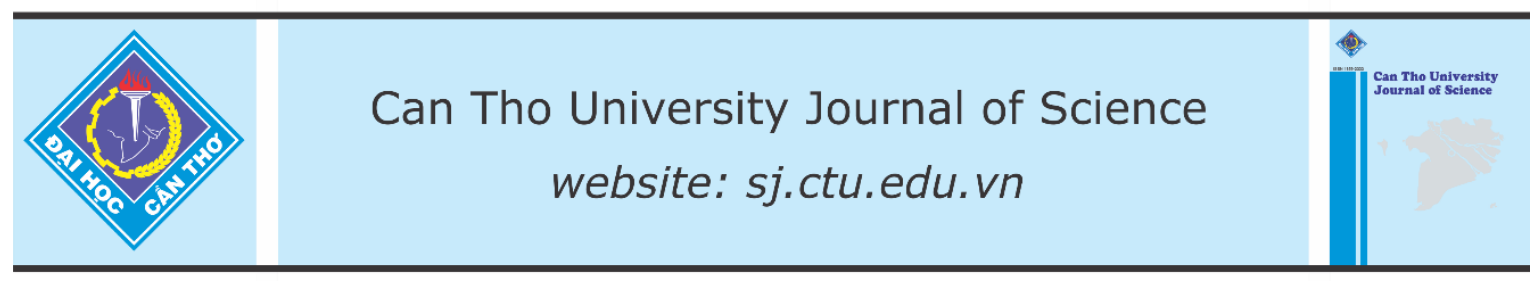

DOI: 10.22144/ctu.jen.2021.027

\title{
Status of using rope in purse seine fisheries in Viet Nam
}

\author{
Dinh Xuan Hung ${ }^{*}$, Nguyen Phan Phuoc Long and Tran Xuan Lam \\ South Research Sub-Institute for Marine Fisheries, Viet Nam \\ *Correspondence: Dinh Xuan Hung (email: dinhhung4@gmail.com)
}

\section{Article info.}

Received 18 Sep 2020

Revised 29 Jan 2021

Accepted 19 Jul 2021

\section{Keywords}

Float line, lead line, main purse line, polypropylene, purse seine, rope diameter

\begin{abstract}
This study is to investigate the status of using rope in purse seine fisheries in Viet Nam based on surveyed data from 13 provinces/cities across country. Statistic data were taken randomly from 30 purse seine samples per each region of North, Middle, and South by pre-designed questionnaire with direct survey method of fishing gears combined with interview with the owners/captains. The results indicated that the initial constructing and annual replacing ropes of purse seine is mainly concentrated in the group of diameters from $10-20 \mathrm{~mm}$. Up to $98 \%$ of Polypropylene (PP) material is used in Vietnamese purse seine. Float line and lead line are used the most ropes in purse seine. In purse seine fisheries, the annual additional rope is one quarter of the original amount of rope fitted. Purse seine in the Middle and the South is larger than that in the North of Viet Nam. The ratio of lengths between the float line and the lead line among the regions is different. The ratio of the main purse line with the lead line ranges from 1.1 to 1.75. Average life expectancy of main purse line is lowest in rope types of the purse seiners. The characteristics of the fishing grounds are different in these three regions, so the rope of purse seine is also different.
\end{abstract}

\section{INTRODUCTION}

The purse seine fishery is focused on strongly by the Vietnamese Government and promoted close access to regional and world technologies. Especially, this fishery can be used to capture in offshore, oceanic areas or/and international fishing cooperation areas. Vietnamese Government focuses on developing the purse seine fishery via the direction of increasing technical quality and modernizing the fleet (Vietnamese Government, 2018). Therefore, there is not increase of boat quantity but fishing capacity improvement by fishing gear technology, fishing supported equipment to match with open-sea area or deep-sea area. In that, rope for purse seine net should be changed in size, material, and structure to ensure efficiency of this boat fleet.
This article is implemented to supply science bases for researching development of material, structure, assessing technical properties of rope types for efficient fishing and sustainable development of marine capture by purse seine in Viet Nam

This article is to assesses the status of purse seine rope utilization in Viet Nam based on field survey samples and memoir interview with the owners and captains in 13 key provinces. This study focused on assessment of the original equipped rope and annual additional rope status of the Vietnamese purse seiners. The rope components of main ring line, lead lines, float line, bunt line, edge line, edge ring line, force line, and wing line were concerned in this article. 


\section{MATERIAL AND METHODS}

\subsection{Subject}

Purse seiners with boat length is from $15 \mathrm{~m}$ or more.

\subsection{Data collection time and methods}

The data are collected from 13 key provinces from $04 / 2020$ to $06 / 2020$ with sample collection methods as:

- Secondary data: 13 key provinces/cities selected represents all 3 regions including the North (Hai Phong, Thanh Hoa, Nghe An, Quang Binh), Central region (Da Nang, Quang Ngai, Binh Dinh, Khanh Hoa), the South (Binh Thuan, Ba Ria - Vung Tau, Ben Tre, Ca Mau, and Kien Giang). The representative sample number is 2 samples per province (except Binh Dinh, Binh Thuan, Ba RiaVung Tau, and Ben Tre has 3 samples per province, because there is a large quantity of purse seiners in the area). The survey questionnaire is pre-designed and used a combined method of memoir interview and direct survey on fishing gear. The questionnaire focused on material, diameter, length, and rope location on purse seine.

- Primary data: purse seiner statistics of 2019 are collected from national and local fisheries management offices. The rope specification data are obtained from the rope manufacturing company.

\subsection{Data analysis methods}

Descriptive statistical method on excel software was used.

- Average value:

$$
\bar{X}=\frac{\sum_{i}^{n} x_{i}}{n}
$$

Where, $\bar{X}$ is average value,

$x_{\mathrm{i}}$ is value at $i$ sample,

$\mathrm{n}$ is total sample.

- Standard deviation:

$$
S=\frac{\sqrt{\sum(x-\bar{x})^{2}}}{n-1}
$$

Where, $\mathrm{S}$ is standard deviation value

$x$ is sample value

$\bar{x}$ is sample average value

$\mathrm{n}$ is total sample

In this paper, the purses seine ropes are divided into two main groups: the original equipment line (the time of fishing gear production) and the annual replenishment line. The method of descriptive statistics was used in this article.

\section{RESULTS AND DISCUSSIONS}

Ropes used for the purse seine fishery in Viet Nam include the main components such as float line, lead line, force rope, edge line, edge ring line, main ring line, bunt line, and wing line. There are different functions and types of ropes in each component.

The research results showed that parts of the buoyancy, lead line, edge line, edge ring line, force rope, bunt line, and wing line are completely (100\%) used Polypropylene (PP) material. Only the main ring line in the South is made of steel cables $(30 \%)$ and PP material cable $(70 \%)$.

\subsection{The original equipment lines}

The float and lead lines are equipped mostly on the purse seine net, averaging approximately 1,800 $\mathrm{m} / \mathrm{boat}$. The float line and lead line of purse seine net in Central provinces are shorted than those in Northern and Southern provinces. However, deep length of purse seine in this area is higher than that in Northern and Southern areas, it was indicated at length of edge line. It is known that the fishing ground characteristic in Northern and Southern areas is shallow depth (less than $100 \mathrm{~m}$ deep), so it is explained for the purse seine net is short depth. In Central area, the depth is over $200 \mathrm{~m}$ and somewhere reaches over $1,000 \mathrm{~m}$. The fishing ground factors affected fishing gear structure of purse seine fishery in Viet Nam; therefore, the length of the rope fitted on the purse seine net differs significantly in each area. 


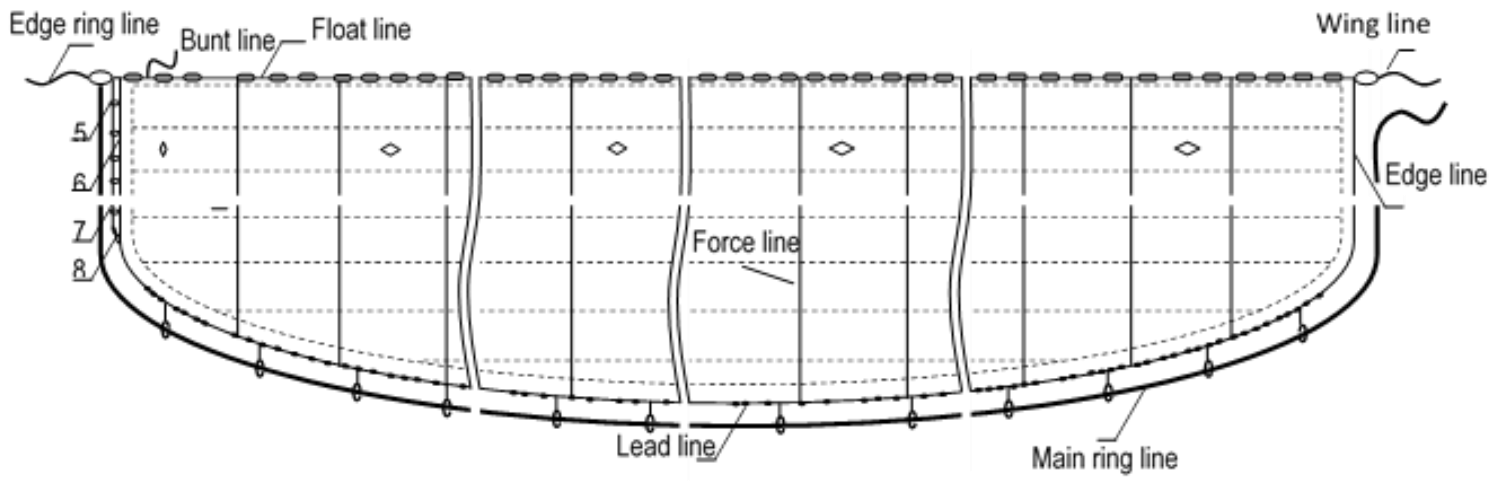

Figure 1. Location of main lines on purse seine net

According to the Vietnamese Standard number of TCVN 12243:2018 on small pelagic fish purse seine (Ministry of Science and Technology, 2018), the length of the float and lead lines does not exceed $800 \mathrm{~m}$. The lead line and float line in this paper is calculating total two ropes with left twist (Z), right twist $(S)$ at each float and lead positions. So, average lead line length or float line length is 900 $\mathrm{m} /$ per one. The result of Najamuddin (2014) indicated that the length of purse seine in South Sulawesi, Indonesia is from $300 \mathrm{~m}$ to $800 \mathrm{~m}$, and the height of the net is from $40 \mathrm{~m}$ to $50 \mathrm{~m}$. From the reference and this result, the average of purse seine length in Viet Nam is higher than domestic Indonesian purse seine net.

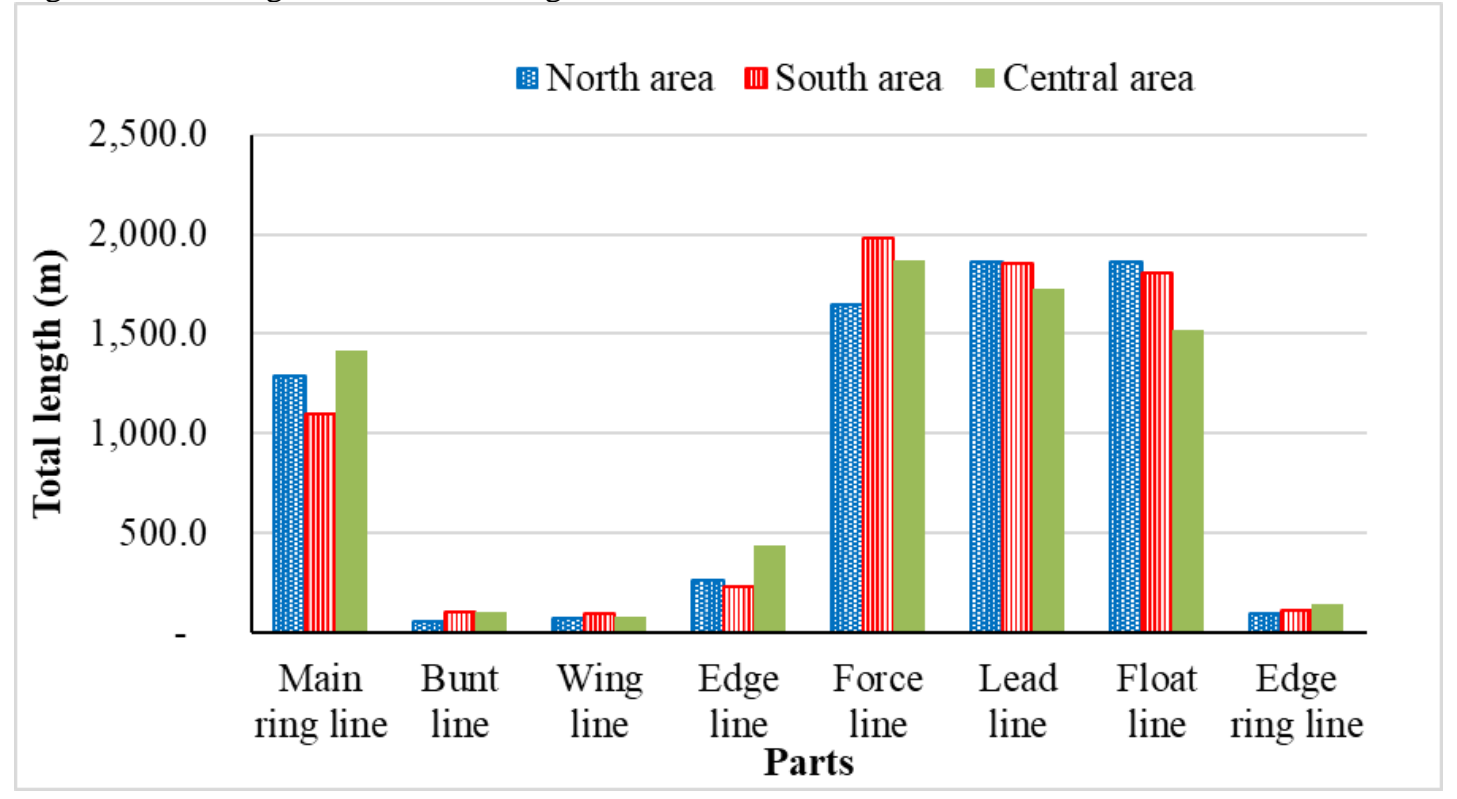

Figure 1. Total rope length of each part of purse seine in Viet Nam

The purse seine in Viet Nam equipped rope diameter from $10 \mathrm{~mm}$ to $20 \mathrm{~mm}$ reaches $52 \%$ and over 40 $\mathrm{mm}$ with $27 \%$ (Figure 2) in total rope length of parts. The rope type diameter range from $10 \mathrm{~mm}$ to $20 \mathrm{~mm}$ is used at float line, lead line, edge line, bunt line, and wing line mainly. Otherwise, main ring line uses rope of over $40 \mathrm{~mm}$ diameter mainly. Rope material in purse seine gear is PP with $99 \%$.
According to FAO Workbook (Prado \& Dremiere, 1990, p. 72), the lead line length is $10 \%$ larger than the float line length, and the main ring line length is 1.1 to 1.75 times larger than the lead line length. The ratio of lead and float ropes of the Vietnamese purse seine in different regions is different and does not comply with the FAO workbook. But the ratio of lead line and main ring line complies with the workbook. 


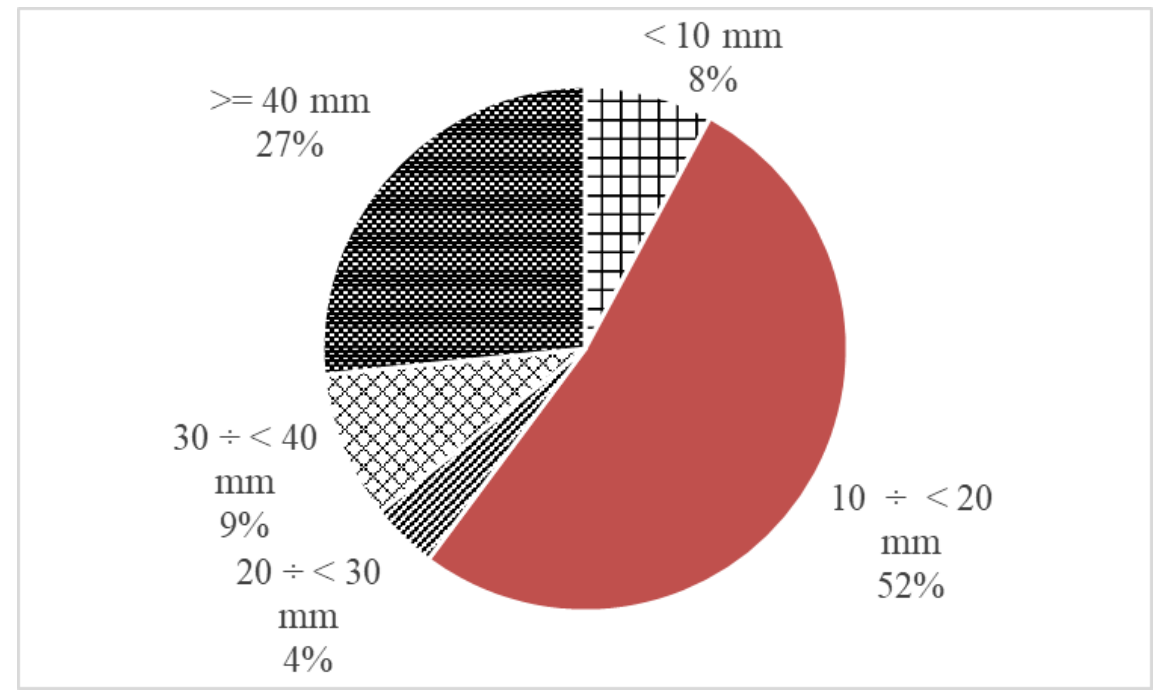

Figure 2. The rate of rope diameter groups used for purse seine in Viet Nam

Table 1. The weight average of the ropes via diameter (the initial equipment) of the purse seine in Viet Nam

\begin{tabular}{crrrrrr}
\hline \multirow{2}{*}{ Diameter (mm) } & \multicolumn{2}{c}{ North Region } & \multicolumn{2}{c}{ Central Region } & \multicolumn{2}{c}{ South Region } \\
\cline { 2 - 7 } & Length(m) & Weight (kg) & Length(m) & Weight(kg) & Length(m) & Weight(kg) \\
\hline 8 & 562,307 & $20,805 \pm 3 \%$ & $2,139,969$ & $79,179 \pm 3 \%$ & $1,860,207$ & $68,828 \pm 3 \%$ \\
10 & 668,968 & $38,332 \pm 3 \%$ & $2,545,888$ & $145,879 \pm 3 \%$ & $2,213,060$ & $126,808 \pm 3 \%$ \\
12 & $\mathbf{1 , 5 8 4 , 7 4 4}$ & $129,632 \pm 3 \%$ & $\mathbf{6 , 0 3 1 , 0 4 9}$ & $493,340 \pm 3 \%$ & $\mathbf{5 , 2 4 2 , 5 9 9}$ & $428,845 \pm 3 \%$ \\
14 & 960,380 & $99,880 \pm 3 \%$ & $3,654,912$ & $380,111 \pm 3 \%$ & $3,177,099$ & $330,418 \pm 3 \%$ \\
16 & 534,133 & $81,188 \pm 3 \%$ & $2,032,745$ & $308,977 \pm 3 \%$ & $1,767,001$ & $268,584 \pm 3 \%$ \\
18 & 142,849 & $27,284 \pm 3 \%$ & 543,638 & $103,835 \pm 3 \%$ & 472,567 & $90,260 \pm 3 \%$ \\
20 & 30,927 & $7,135 \pm 3 \%$ & 117,698 & $27,153 \pm 3 \%$ & 102,311 & $23,603 \pm 3 \%$ \\
22 & 83,326 & $23,665 \pm 3 \%$ & 317,113 & $90,060 \pm 3 \%$ & 275,656 & $78,286 \pm 3 \%$ \\
24 & 46,615 & $14,754 \pm 3 \%$ & 177,404 & $56,148 \pm 3 \%$ & 154,212 & $48,808 \pm 3 \%$ \\
28 & 9,323 & $4,056 \pm 3 \%$ & 35,481 & $15,434 \pm 3 \%$ & 30,842 & $13,416 \pm 3 \%$ \\
30 & 50,152 & $25,076 \pm 3 \%$ & 190,862 & $95,431 \pm 3 \%$ & 165,910 & $82,955 \pm 3 \%$ \\
32 & 27,918 & $16,444 \pm 3 \%$ & 106,247 & $62,579 \pm 3 \%$ & 92,357 & $54,398 \pm 3 \%$ \\
34 & 25,076 & $16,094 \pm 3 \%$ & 95,431 & $61,248 \pm 3 \%$ & 82,955 & $53,241 \pm 3 \%$ \\
36 & 78,978 & $57,773 \pm 3 \%$ & 300,567 & $219,865 \pm 3 \%$ & 261,273 & $191,121 \pm 3 \%$ \\
38 & 198,729 & $160,971 \pm 3 \%$ & 756,303 & $612,606 \pm 3 \%$ & 657,430 & $532,519 \pm 3 \%$ \\
40 & 57,760 & $52,331 \pm 3 \%$ & 219,818 & $199,155 \pm 3 \%$ & 191,081 & $173,119 \pm 3 \%$ \\
42 & 195,034 & $159,538 \pm 3 \%$ & 742,241 & $607,153 \pm 3 \%$ & 645,207 & $527,779 \pm 3 \%$ \\
44 & 18,110 & $16,028 \pm 3 \%$ & 68,922 & $60,996 \pm 3 \%$ & 59,912 & $53,022 \pm 3 \%$ \\
45 & 62,904 & $58,186 \pm 3 \%$ & 239,393 & $221,439 \pm 3 \%$ & 208,097 & $192,490 \pm 3 \%$ \\
46 & 14,574 & $14,326 \pm 3 \%$ & 55,464 & $54,521 \pm 3 \%$ & 48,213 & $47,394 \pm 3 \%$ \\
48 & 33,434 & $35,808 \pm 3 \%$ & 127,241 & $136,276 \pm 3 \%$ & 110,607 & $118,460 \pm 3 \%$ \\
50 & 630,438 & $740,765 \pm 3 \%$ & $2,399,255$ & $2,819,124 \pm 3 \%$ & $2,085,596$ & $2,450,575 \pm 3 \%$ \\
52 & 33,434 & $42,763 \pm 3 \%$ & 127,241 & $162,742 \pm 3 \%$ & 110,607 & $141,466 \pm 3 \%$ \\
55 & 208,966 & $273,640 \pm 3 \%$ & 795,259 & $1,041,391 \pm 3 \%$ & 691,293 & $905,248 \pm 3 \%$ \\
\hline Total & $6,259,081$ & $2,116,472 \pm 3 \%$ & $23,820,141$ & $8,054,642 \pm 3 \%$ & $20,706,094$ & $7,001,645 \pm 3 \%$ \\
\hline
\end{tabular}

The average number in Table 1 was based on fishing purse seiner statistics in 2019 from Directorate of Fisheries. This number may be change in future when number of the boats are changed.
The rope of $12 \mathrm{~mm}$ diameter accounts for the highest proportion in all 3 regions with corresponding values of approximately $1,600,000 \mathrm{~m} ; 6,000,000$ $\mathrm{m}$; and 5,200.00 $\mathrm{m}$ for the Northern, Central and Southern regions, respectively. 
The total PP rope weight of purse seine in the Central is the highest. The purse seine rope in the Northern is used 3.8 times less than that in the Center region and 3.3 times less than that in the Southern region

\subsection{Annual addition rope}

Among the main components, the buoy and lead lines have the most annual rope additions.

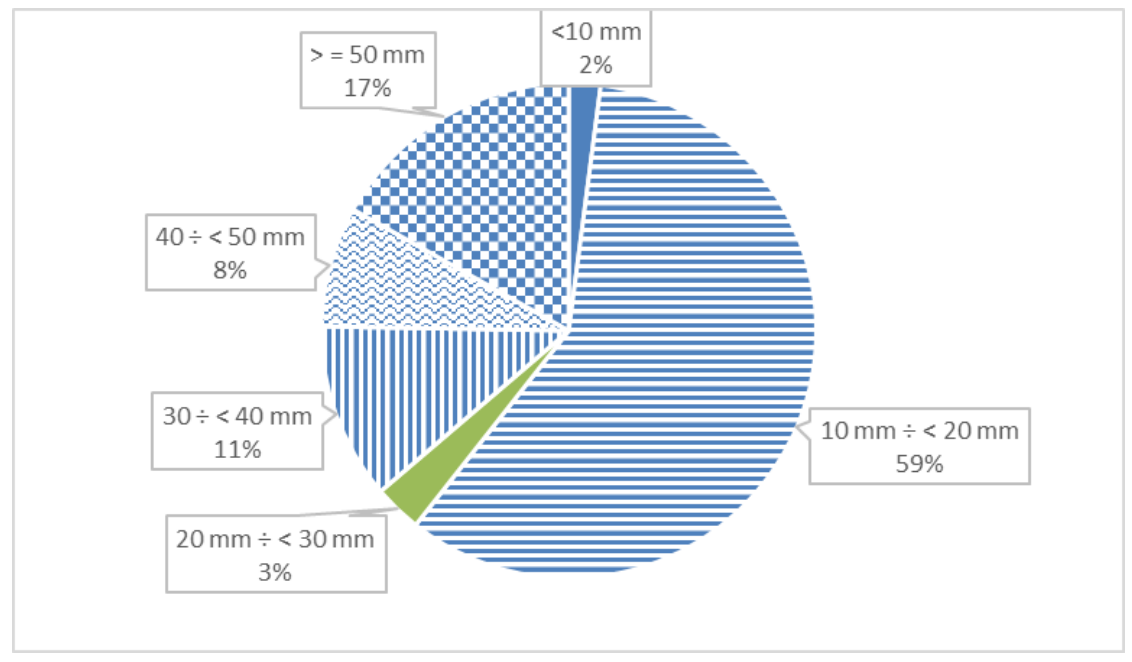

Figure 3. Ropes supplementation rate of the purse seine fishery in Viet Nam

The results showed that like the original equipment, PP rope with diameters from $10 \mathrm{~mm}$ to 20 $\mathrm{mm}$ accounted for the largest supplement rate with $59 \%$.

The annual added ropes by purse seine is only $1 / 5$ of its original equipment (Table $2 \& 1$ ). The $12 \mathrm{~mm}$ diameter ropes still account for the highest supplement rate with $294,365 \mathrm{~m}$ in the North, 1,120,264 $\mathrm{m}$ in the Central region and $973,810 \mathrm{~m}$ in the South. The rope supplementation level of purse seine in the Central region is the highest in Viet Nam. This showed that the development scale of the purse seine fishery is strongly concentrated in the Central region of Viet Nam. In the strategy of developing the marine fisheries with purse seine towards offshore and deep-sea exploitation and international cooperation in fishing, the purse seine fishery in Central Viet Nam can get closer to the rest area. However, the current site using ropes shows only a small part of the scale of the purse seine industry in Viet Nam.

In the strategy for the development of the marine fishing industry, the purse seine is prioritized to improve the fishing capacity of technique field, in which the improvement of fishing gears, mechanization and application of fish finding technology. Improving and developing new materials and technical properties of ropes used in fisheries are also the goal of Viet Nam and other countries in the world in general. With such a large amount of annual supplementary ropes as above analysis, it should be necessary to promote research to create more environmentally friendly rope products.

In the Central region, the fishing ground is similar with open sea characteristics and differed other regions in Viet Nam seawater about depth, marine condition, and weather condition. On the other hand, the fish species catch often is small tuna like skipjack tuna, long-tail tuna, Eastern little tuna, frigate mackerel, bullet tuna, juvenile yellowfin and bigeye tuna. The swim speed of these species is fast. So, the technical characteristic of purse seine net is also higher for other species, and the net is damaged easily in operation process.

The development strategy of purse seine fisheries in Viet Nam, the gear technology should be based on purse seine net features in the Central region.

In 2016, Hung et al. assessed Vietnamese tuna purse seine technology characteristics by numerical method. This research also indicated that the technology properties of purse seine net in the Central region is better than those of purse seine net in the South. The technology properties of purse seine from 2014 is better than those from 2003. The original technology properties of the net are impacted strongly to catch efficient (Hung et al., 2016). 
Table 2. The weight of annual supplement rope of purse seine fishery in Viet Nam

\begin{tabular}{crrrrrr}
\hline \multirow{2}{*}{$\begin{array}{c}\text { Diameter } \\
(\mathbf{m m})\end{array}$} & \multicolumn{2}{c}{ North region } & \multicolumn{2}{c}{ Central region } & \multicolumn{2}{c}{ South region } \\
\cline { 2 - 7 } & Length $(\mathbf{m})$ & Weight (kg) & Length (m) & Weight (kg) & Length (m) & Weight (kg) \\
\hline 8 & 26,469 & $979 \pm 3 \%$ & 100,733 & $3,727 \pm 3 \%$ & 87,564 & $3,240 \pm 3 \%$ \\
10 & 139,199 & $7,976 \pm 3 \%$ & 529,748 & $30,355 \pm 3 \%$ & 460,493 & $26,386 \pm 3 \%$ \\
12 & 294,365 & $24,079 \pm 3 \%$ & $1,120,264$ & $91,638 \pm 3 \%$ & 973,810 & $79,658 \pm 3 \%$ \\
14 & 163,512 & $17,005 \pm 3 \%$ & 622,278 & $64,717 \pm 3 \%$ & 540,926 & $56,256 \pm 3 \%$ \\
16 & 93,227 & $14,170 \pm 3 \%$ & 354,793 & $53,928 \pm 3 \%$ & 308,410 & $46,878 \pm 3 \%$ \\
18 & 60,741 & $11,601 \pm 3 \%$ & 231,161 & $44,152 \pm 3 \%$ & 200,941 & $38,380 \pm 3 \%$ \\
20 & 7,688 & $1,774 \pm 3 \%$ & 29,257 & $6,750 \pm 3 \%$ & 25,432 & $5,867 \pm 3 \%$ \\
22 & 22,255 & $6,320 \pm 3 \%$ & 84,695 & $24,054 \pm 3 \%$ & 73,623 & $20,909 \pm 3 \%$ \\
24 & 9,012 & $2,852 \pm 3 \%$ & 34,298 & $10,855 \pm 3 \%$ & 29,814 & $9,436 \pm 3 \%$ \\
28 & 1,243 & $541 \pm 3 \%$ & 4,731 & $2,058 \pm 3 \%$ & 4,112 & $1,789 \pm 3 \%$ \\
30 & 10,368 & $5,184 \pm 3 \%$ & 39,457 & $19,729 \pm 3 \%$ & 34,299 & $17,149 \pm 3 \%$ \\
32 & 11,841 & $6,975 \pm 3 \%$ & 45,065 & $26,543 \pm 3 \%$ & 39,173 & $23,073 \pm 3 \%$ \\
34 & 12,538 & $8,047 \pm 3 \%$ & 47,716 & $30,624 \pm 3 \%$ & 41,478 & $26,620 \pm 3 \%$ \\
36 & 50,988 & $37,297 \pm 3 \%$ & 194,043 & $141,943 \pm 3 \%$ & 168,676 & $123,386 \pm 3 \%$ \\
38 & 61,937 & $50,169 \pm 3 \%$ & 235,715 & $190,929 \pm 3 \%$ & 204,899 & $165,968 \pm 3 \%$ \\
40 & 20,779 & $18,825 \pm 3 \%$ & 79,077 & $71,644 \pm 3 \%$ & 68,739 & $62,278 \pm 3 \%$ \\
42 & 47,366 & $38,745 \pm 3 \%$ & 180,259 & $147,452 \pm 3 \%$ & 156,693 & $128,175 \pm 3 \%$ \\
44 & 5,015 & $4,438 \pm 3 \%$ & 19,086 & $16,891 \pm 3 \%$ & 16,591 & $14,683 \pm 3 \%$ \\
45 & 13,786 & $12,752 \pm 3 \%$ & 52,467 & $48,532 \pm 3 \%$ & 45,608 & $42,187 \pm 3 \%$ \\
46 & 2,883 & $2,834 \pm 3 \%$ & 10,970 & $10,784 \pm 3 \%$ & 9,536 & $9,374 \pm 3 \%$ \\
48 & 11,145 & $11,936 \pm 3 \%$ & 42,414 & $45,425 \pm 3 \%$ & 36,869 & $39,487 \pm 3 \%$ \\
50 & 165,399 & $194,344 \pm 3 \%$ & 629,457 & $739,612 \pm 3 \%$ & 547,167 & $642,921 \pm 3 \%$ \\
52 & 11,145 & $14,254 \pm 3 \%$ & 42,414 & $54,247 \pm 3 \%$ & 36,869 & $47,155 \pm 3 \%$ \\
55 & 39,564 & $51,809 \pm 3 \%$ & 150,569 & $197,170 \pm 3 \%$ & 130,885 & $171,394 \pm 3 \%$ \\
\hline Total & $1,282,464$ & $544,909 \pm 3 \%$ & $4,880,665$ & $2,073,756 \pm 3 \%$ & $4,242,608$ & $1,802,651 \pm 3 \%$ \\
\hline
\end{tabular}

The rope equipment on purse seine also depends on fishing ground. The fishing ground in Centre area from Da Nang to Ninh Thuan provinces is so depth, so the purse seine net is bigger than other purse seine net in Viet Nam.

\section{CONCLUSIONS}

For Vietnamese purse seine characterizes, the rope material is main Polypropylene and the commonly rope diameter ranges from $8 \mathrm{~mm}$ to $55 \mathrm{~mm}$, that, the $12 \mathrm{~mm}$ diameter rope is the most popular. The ratio of the main purse line with the lead line ranges from 1.1 to 1.75 .

In annually, PP ropes are supplied for purse seine significantly, in which, rope for purse seine fishery in the Central region account for largest proportion in the whole country.

\section{REFERENCES}

Hung, D. X., Lee, C. W., \& Park, S., (2016). Dynamic analysis and improvement of the sinking performance of the Vietnamese tuna purse seine using numerical methods. Journal of the Korean Society of
Fisheries and Ocean Technology, 52(1), 1-8. https://doi.org/10.3796/KSFT.2016.52.1.001

Prado, J., \& Dremiere, P. Y. (1990). Fisherman's workbook. Fishing News Books. http://www.fao.org/3/ah827e/ah827e.pdf

Najamuddin, N., (2014, October 9-10). Purse seine design and construction in Barru District Waters South Sulawesi. Proceeding of the 3rd International Seminar of Fisheries and Marine Science, Pekanbaru, Indonesia. https://www.researchgate.net/publication/298058213 purse_seine_design_and_construction_in_barru_distri ct_waters_south_sulawesi

Ministry of Science and Technology. (2018). Fishing equipment - small pelagic purse seine (TCVN No. 12243:2018). https://vanbanphapluat.co/tcvn-122432018-thiet-bi-khai-thac-thuy-san

Vietnamese Government (2018). Amendment to some articles of the government's Decree No. 67/2014/NĐ-CP dated on July 07th, 2014 on some seafood development policies (The Decree No. 17/2018/NĐ-CP dated on January 02 ${ }^{\text {sd }}, 2018$ ). http://vanban.chinhphu.vn/portal/page/portal/chinhph u/hethongvanban?class_id=1\&_page $=1 \&$ mode $=$ detai 1\&document_id=192897 